\title{
Melt-peridotite interactions recorded in xenoliths from the Feuerberg volcano complex, West Eifel, Germany.
}

\author{
S. Koch and A.B. Woodland \\ Institut für Geowissenschaften, Universität Frankfurt, Altenhöferallee 1, 60438 Frankfurt, Germany \\ woodland@em.uni-frankfurt.de
}

The Neogene age West Eifel volcanic field is well known for its ultramafic xenoliths, many of which exhibit various degrees and types of metasomatism. The textures and chemistry of the xenoliths reveal important information regarding timing of this interaction and allow us to discern whether these processes happened in the mantle or during transport and emplacement. Here we report the results of an investigation of a suite of peridotite xenoliths from the Feuerberg volcano complex, a locality that has not been previously studied.

Feuerberg lies approximately in the middle of the West Eifel field, $5 \mathrm{~km} \mathrm{NE}$ of Gerolstein. This locality is an operating open pit quarry. The volcanic complex is $\sim 1 \times 0.5 \mathrm{~km}$ in size and comprises cinder cones with associated tephra horizons along with a short late-stage lava flow. The pyroclastic deposits are olivine-melilite-nephelinite in composition (Meyer 1986). More than 50 samples were collected from a single lapilli-tuff horizon located near the bottom of the exposed volcanic succession. The high proportion of country rock fragments testify to the phreatomagmatic character of this unit. From a subset of 15 xenoliths, 9 were chosen for detailed investigation.

\section{Sample description}

The xenoliths studied range in size from 4 to $10 \mathrm{~cm}$ across. Some are well rounded, while others have an angular form caused by breakage during eruption. The xenolith suite is comprised essentially of wehrlite $(c p x+o l+s p \pm$ glass \pm phlog), although a few samples contain rare, large opx (Fig. 1). Megascopic and microscopic textures reveal they were previously course grained harzburgites, which have been modified by variable degrees of melt infiltration and reaction. In 4 of 9 samples, a planar texture is apparent that is truncated at the xenolith margins (Fig. 1). The other samples also have truncated textural features. We interpret this as evidence for metasomatism in the mantle prior to entrainment by the host magma. The intensity of metasomatism is variable from sample to sample (and even within a single xenolith) and is generally expressed in terms of the amount of newly formed cpx. Most samples contain no primary cpx.

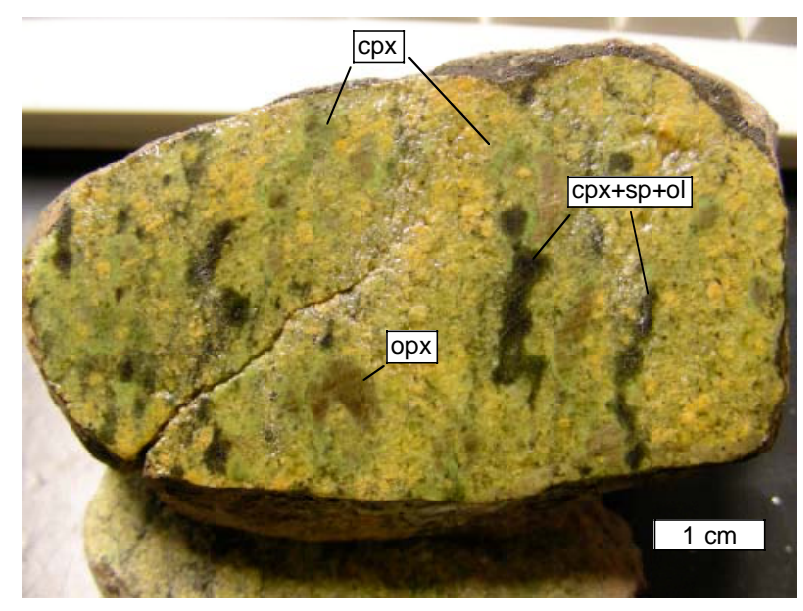

Figure 1. Xenolith FB-05 illustrating a crude planar texture dominated by added cpx. This texture is truncated at the xenolith margins. A few large opx grains are present. Also lying within the planar structure are dark patches of $\mathrm{cpx}+\mathrm{sp}+\mathrm{ol}$.

Reaction textures

A number of reaction textures are present, reflecting different types of metasomatism. One type of reaction texture has developed adjacent to large primary opx, indicating reaction with an infiltrating melt (Shaw 1999; Shaw \& Dingwell 2007). Here, patches of $\mathrm{cpx}+\mathrm{ol}+\mathrm{sp}+$ glass have formed at the grain margins and within the opx grains (Fig.2). The newly formed olivine has a composition $\mathrm{X}_{\mathrm{fo}} \sim 0.91$ and the glass is very $\mathrm{SiO}_{2}$-rich (>60 wt \%, see $\mathrm{Tab} .1$ ), consistent with that observed by Shaw (1999).

Fine idiomorphic Cpx occurs in variably developed pockets along with ol, sp, glass and bubbles (Fig. 3). Newly formed olivine is richer in $\mathrm{Mg}$ $\left(\mathrm{X}_{\mathrm{fo}}=0.94\right), \mathrm{Ca}$ and $\mathrm{Ni}$ than the primary ol $\left(\mathrm{X}_{\mathrm{fo}} \sim 0.90\right)$ and sits within a glass with $\sim 48 \mathrm{wt} \% \mathrm{SiO}_{2}$ and rich in $\mathrm{TiO}_{2}$ and alkalis (Tab. 1). Textures and mineral compositions suggest these may have developed 


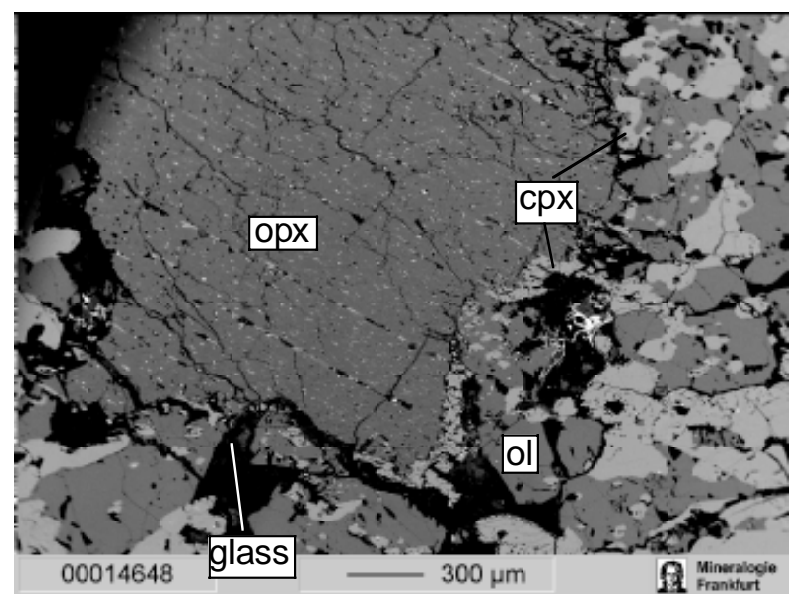

Figure 2. Backscattered electron image of large primary opx in sample FB-04. Note the reaction forming cpx, olivine and glass at the expense of opx.

Table 1. Selected compositions of glass and mineral phases.

\begin{tabular}{|c|c|c|c|c|c|c|c|c|}
\hline & $\begin{array}{l}\text { Glass } \\
\text { he is opy }\end{array}$ & $\begin{array}{l}\text { Glass } \\
\text { fpocket }\end{array}$ & $\begin{array}{l}\text { Cpx } \\
\text { ne ar opx }\end{array}$ & $\begin{array}{l}\text { Cpx } \\
\text { pocket }\end{array}$ & $\begin{array}{l}\text { Spinel } \\
\text { sieve }\end{array}$ & $\begin{array}{l}01 \\
\text { primary }\end{array}$ & $\begin{array}{l}01 \\
\text { pocket }\end{array}$ & $\begin{array}{l}01 \\
\text { ne ar opx }\end{array}$ \\
\hline $\mathrm{SiO}_{1}$ & 68.39 & 48.43 & 54.17 & 54.47 & \begin{tabular}{|l}
0.05 \\
\end{tabular} & 41.08 & 41.41 & 40.81 \\
\hline $\mathrm{TiO}_{2}$ & 19 & 1.68 & 0.10 & 0.06 & 0.34 & nd & nd & .01 \\
\hline $\mathrm{Al}_{2} \mathrm{O}_{1}$ & 14.16 & 20.64 & 2.85 & 1.20 & 17.65 & nd & 0.06 & 0.01 \\
\hline $\mathrm{Cr}_{1} \mathrm{O}_{1}$ & 0.04 & 0.05 & 1.88 & 0.98 & 50.13 & 0.03 & 0.06 & 0.11 \\
\hline $\mathrm{FeO}$ & 2.24 & 4.01 & 2.98 & 2.78 & 18.14 & 9.79 & 6.27 & 8.32 \\
\hline Mino & 0.03 & 0.05 & 0.15 & .12 & 0.32 & 0.23 & 0.11 & 0.21 \\
\hline $\mathrm{HiO}$ & nd & nd & 0.06 & 0.01 & 0.13 & 0.37 & 0.41 & 0.18 \\
\hline $\mathrm{M} \approx 0$ & 1.78 & 3.47 & 17.41 & 17.36 & 14.82 & 49.98 & 51.88 & 50.98 \\
\hline $\mathrm{CaO}$ & 1.02 & 10.12 & 19.83 & 21.99 & nd & 0.11 & 0.22 & 0.14 \\
\hline $\mathrm{Ha}_{2} \mathrm{O}$ & 4.26 & 6.95 & 1.35 & 1.08 & 0.01 & 0.02 & 0.01 & 0.02 \\
\hline $\mathrm{K}_{2} \mathrm{O}$ & 6.01 & 3.24 & nd & 0.02 & & & & \\
\hline Total & 98.16 & 99.56 & 100.80 & 100.09 & 101.63 & 101.60 & 100.45 & 100.92 \\
\hline
\end{tabular}

through decompression melting of amphibole (Shaw \& Klügel 2002; Ban et al. 2005). This would be consistent with the high volatile content implied by the numerous bubbles. However, this interpretation would imply very large proportions of amphibole in these samples even though no relicts of amphibole are currently present. In fact no amphibole has been found in any of the xenoliths studied.

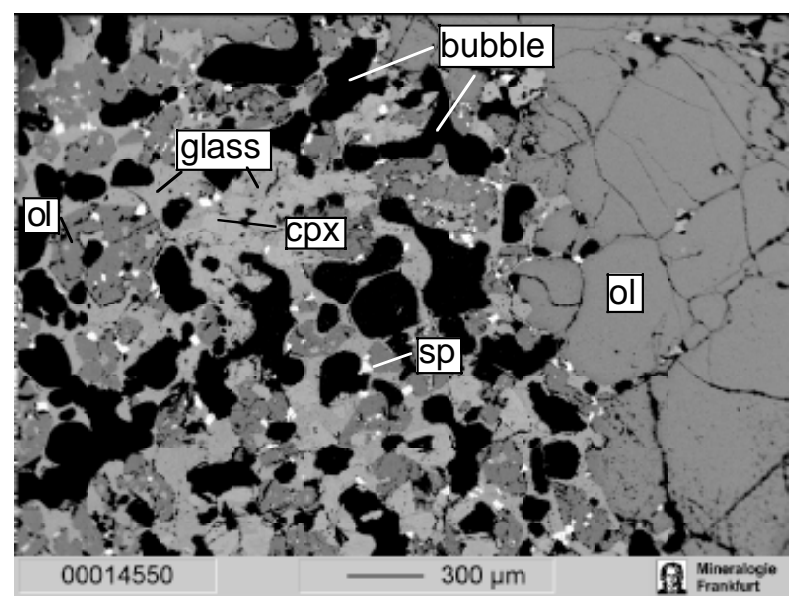

Figure 3. Backscattered electron image of sample FB10a, illustrating a cpx-rich pocket, also containing idiomorphic olivine and spinel, embedded in glass and bubbles . Note the primary olivine to the right side.
In yet other samples, clusters of sieve-textured spinel with fine $\mathrm{cpx} \pm$ phlogopite occur, signalling a further type of melt-peridotite reaction (Fig. 4). The cpx and phlogopite is both intergrown with spinel and also forms a mantle around the spinel grains. The spinel is Cr-rich, consistent with a harzburgitic composition (Tab.1). In one instance where phlogopite was not present (FB-05), the spinel has a different texture, olivine is present and the cpx grains are idiomorphic.

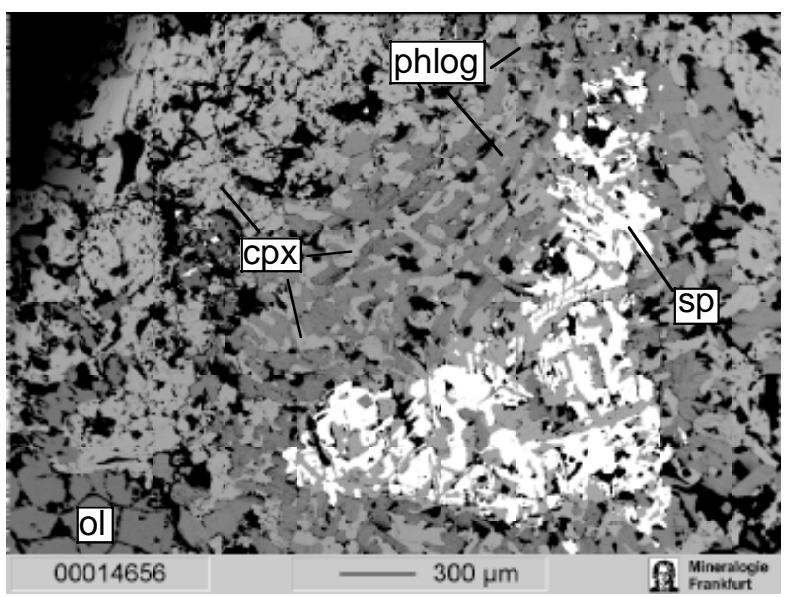

Figure 4. Backscattered electron image of a sievetextured spinel embedded in a mass of cpx and phlogopite from samples FB-04.

Reaction between the host magma and the xenolith is limited to its outermost margins. Here, primary olivine is zoned with rims of $\mathrm{X}_{\mathrm{fo}} \sim 0.86$. Locally developed clusters of $\mathrm{cpx}+\mathrm{ol}$ are also present at the xenolith margins. The compositions of these two phases are similar to phenocrysts in the lava and are distinct from those grains occurring within the xenoliths.

This xenolith suite demonstrates that many types of melt-peridotite reaction can occur at a single locality and even a single sample, complicating the interpretation of the metasomatic processes. Textural and compositional parameters must be considered together in order to understand such processes.

\section{References}

Ban, M., Witt-Eickschen, G., Klein, M., Seck, H.A. (2005) The origin of glasses in hydrous mantle xenoliths from the West Eifel, Germany: incongruent breakdown of amphibole. Contrib Mineral Petrol, 148, 511-523

Meyer, W. (1986) Geologie der Eifel.

Schweizerbart'scher Verlag, Stuttgart, pp. 614.

Shaw, C.S.J. (1999) Dissolution of orthopyroxene in basanitic magma between 0.4 and $2 \mathrm{GPa}$ : further implications for the origin of Si-rich alkaline glass inclusions in mantle xenoliths. Contrib Mineral Petrol, 135,114-132.

Shaw, C.S.J., Dingwell, D.B. (2007) Experimental peridotite-melt reaction at one atmosphere: a textural and chemical study. Contrib Mineral Petrol, DOI 10.1007/s00410-007-0237-1 
Shaw, C.S.J., Klügel, A. (2002) The pressure and temperature conditions and timing of glass formation in mantle-derived xenoliths from Baarley, West Eifel, Germany: the case for amphibole breakdown, lava infiltration and mineral-melt reaction. Mineral Petrol, 74, 163187 